Viewpoint

\title{
Good Environmental Status of marine ecosystems: What is it and how do we know when we have attained it?
}

\author{
Angel Borja ${ }^{\mathrm{a}, *}$, Mike Elliott ${ }^{\mathrm{b}}$, Jesper H. Andersen ${ }^{\mathrm{c}}$, Ana C. Cardoso ${ }^{\mathrm{g}}$, Jacob Carstensen ${ }^{\mathrm{c}}$, João G. Ferreira ${ }^{\mathrm{d}}$, \\ Anna-Stiina Heiskanen ${ }^{\mathrm{e}}$, João C. Marques ${ }^{\mathrm{f}}$, João M. Neto ${ }^{\mathrm{f}}$, Heliana Teixeira ${ }^{\mathrm{g}}$, Laura Uusitalo ${ }^{\mathrm{e}}$, \\ María C. Uyarra ${ }^{a}$, Nikolaos Zampoukas ${ }^{g}$

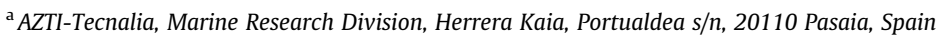 \\ ${ }^{\mathrm{b}}$ Institute of Estuarine \&' Coastal Studies, University of Hull, Hull HU6 7RX, UK \\ ${ }^{\mathrm{C}}$ University of Aarhus, Department of Bioscience, P.O. Box 358, DK-4000 Roskilde, Denmark \\ ${ }^{\mathrm{d}}$ IMAR - Marine and Environmental Research Centre, Dept. Ciências e Engenharia do Ambiente, Faculdade de Ciências e Tecnologia, Universidade Nova de Lisboa, \\ Quinta da Torre, 2829-516 Monte de Caparica, Portugal \\ e SYKE - Finnish Environment Institute, Marine Research Centre, P.O. Box 140, FIN-00251 Helsinki, Finland \\ ${ }^{\mathrm{f}}$ IMAR - Institute of Marine Research, Marine and Environmental Research Centre, Faculty of Sciences and Technology, University of Coimbra, 3004-517 Coimbra, Portugal \\ ${ }^{\mathrm{g}}$ European Commission, Joint Research Centre, Institute for Environment and Sustainability, 21027 Ispra, Italy
}

\section{A R T I C L E I N F O}

\section{Keywords:}

Assessment

Good Environmental Status

Descriptors

Indicators

Integration

Marine Strategy Framework Directive

\begin{abstract}
A B S T R A C T
The European Marine Strategy Framework Directive (MSFD) requires EU Member States (MS) to achieve Good Environmental Status (GEnS) of their seas by 2020. We address the question of what GEnS entails especially with regard to the level at which targets are set (descriptors, criteria, indicators), to scales for assessments (regional, sub-divisions, site-specific), and to difficulties in putting into practice the GEnS concept. We propose a refined and operational definition of GEnS, indicating the data and information needed to all parts of that definition. We indicate the options for determining when GEnS has been met, acknowledge the data and information needs for each option, and recommend a combination of existing quantitative targets and expert judgement. We think that the MSFD implementation needs to be less complex than shown for other similar directives, can be based largely on existing data and can be centred on the activities of the Regional Seas Conventions.
\end{abstract}

(c) 2013 Elsevier Ltd. All rights reserved.

\section{Introduction}

Marine waters have traditionally been used by society for different activities (e.g. fishing, aquaculture, shipping, tourism, discharges from agriculture and urban areas). Currently, new activities are being developed or increasing (e.g. renewable energies, extraction of minerals, etc.), and thus competing for space with traditional uses, causing many spatial conflicts and increasing human impacts on marine ecosystems (Ban and Alder, 2008; Halpern et al., 2008). While the legal framework for 'marine spatial planning and coastal development' is relatively new (Ehler and Douvere, 2009; European Commission, 2013), most of the legislation to protect, conserve or enhance marine ecosystems is based upon the United Nations Convention on the Law of the Sea (UNCLOS, 1982).

In Europe, there are two main Directives focusing on these topics: (i) the Water Framework Directive (WFD, 2000/60/EC; European Commission, 2000), which, covers transitional and coastal waters up to $1 \mathrm{~nm}$ from the continental baseline, and (ii) the Marine

\footnotetext{
* Corresponding author. Tel.: +34 667174 430; fax: +34 946572555 .

E-mail address: aborja@azti.es (A. Borja).
}

Strategy Framework Directive (MSFD, 2008/56/EC; European Commission, 2008), covering all marine waters up to the limit of the Exclusive Economic Zone (EEZ) and extended continental shelf. In addition, there is a proposed Directive for Maritime Spatial Planning and Integrated Coastal Management (European Commission, 2013) which will integrate management and planning.

Both the existing Directives try to ensure that the marine use is compatible with the conservation of ecosystems and the maintenance of the good status of waters, habitats and resources. The MSFD aims to achieve or maintain 'good environmental status' (GEnS) in marine waters, by 2020 (European Commission, 2008), whilst the WFD aims to achieve 'good ecological status' (GECS) in transitional and coastal waters, by 2015 . Following the recommendation from Mee et al. (2008), we use the GEnS and GEcS acronyms because the meaning of 'environmental' and 'ecological' is different (see Borja et al. (2010), for differences between both concepts), implying a different emphasis between these two major pieces of legislation.

It has been argued that GEcS, as required by the WFD, focuses more on ecological structure, i.e. at a given time the abundance, presence, cover, etc., of ecological components, referred to as biological quality elements (Heiskanen et al., 2004; Borja et al., 
2010), i.e. phytoplankton, macrophytes, macroinvertebrates and fish (the latter not in marine waters). In turn, the concept of environmental status, as defined by the MSFD, takes into account the structure, function and processes of marine ecosystems, bringing together natural physical, chemical, physiographic, geographic and climatic factors, and integrates these conditions with anthropogenic impacts and activities carried out in the area of concern (European Commission, 2008). Hence, it has been argued that, in using wider descriptors which relate to pressures, the MSFD provides a functional approach to measuring ecosystem health, where 'functional' refers to rate (i.e. time-dependent) processes (Borja et al., 2010).

According to the MSFD, the environmental status is defined by 11 descriptors, and forms a proposed set of 29 associated criteria and 56 indicators that include biological, physico-chemical indicators as well as pressure indicators-including hazardous substances, hydrological alterations, litter and noise, and biological disturbance such as introduction of non-indigenous species (Cardoso et al., 2010; European Commission, 2010) (Table 1). Following the implementation schedule of the MSFD, EU Member States (MS) started to assess the environmental status of their marine waters in 2012. This assessment should be carried out in an integrative way, including measurement of many ecosystem components together with physicochemical parameters and elements of pollution (Borja et al., 2009). However, in most countries, the precise means of implementing the MSFD are yet unclear. In most cases MS are focusing on individual descriptors and then criteria and indicators within the descriptors, with apparently little or no attention being paid to the means of combining the indicators, criteria and descriptors into a holistic assessment of the environmental status (http:// ec.europa.eu/environment/marine/public-consultation/index_en. htm). Although several attempts have been made to assess the environmental status of marine waters in an integrative manner (HELCOM, 2010; Borja et al., 2011), there are still significant gaps regarding: (i) the understanding of marine ecosystems and their responses to human activities, including climate change; (ii) the baseline knowledge required to define GEnS in an adequate and operational way; (iii) the meaning of GEnS itself, and (iv) the identification, measurement and weighting of the components of the different indicators. For example, one indicator of biodiversity is the distribution range of species. However, the questions on how many species should be taken into account, whether all species are equally important, whether they should be considered as groups or as species and on a seasonal or annual basis, are yet to be answered (Borja et al., 2010).

To assist MS in determining GEnS, several principles were highlighted in a Common Understanding document (Claussen et al., 2011). However, we contend that these do not provide an operational approach nor tackle the fundamental question of how to integrate all the aspects of assessment within and among marine areas. Here we highlight those principles that could help to answer two main questions: what is GEnS and how do we know when it is attained? In particular, we focus on: (i) the conceptual definition of GEnS and related problems (e.g. the different steps for selecting criteria/indicators and the proposal of minimum common approaches); (ii) the role of setting of targets to determine GEnS; (iii) the existing approaches for integrating assessment results, from the indicator level up to the level of GEnS of a marine area, and (iv) an operational definition of GEnS, with the challenges for deriving and using it.

\section{Current definition of Good Environmental Status and associated problems}

The MSFD defines GEnS as "the environmental status of marine waters where these provide ecologically diverse and dynamic oceans and seas which are intrinsically clean, healthy and productive, and the use of the marine environment is at a level that is sustainable, thus safeguarding the potential for uses and activities by current and future generations" (European Commission, 2008). Hence, this implicitly requires ecosystem services and societal benefits to be delivered (Atkins et al., 2011a,b) even though the descriptors and their proposed criteria do not mention these aspects.

The concept of environmental status and the normative definitions of GEnS relate to the structure and successful functioning of ecosystems which allow them to maintain their resilience to human-induced environmental change (Elliott et al., 2007). This means that marine species and habitats are protected, human-induced decline of biodiversity is prevented, and diverse biological components are in balance. In addition, hydrographical, physical and chemical properties of the ecosystems, including those which result from human activities, support the ecosystems as described above. Finally, anthropogenic inputs of substances and energy, including noise, into the marine environment do not cause significant adverse effects to marine environment and allow ecosystem services and societal benefits to be maintained and delivered (Atkins et al., 2011a,b). There is, however, little understanding of what to consider as a meaningful quantitative definition of GEnS for a marine area, despite the stipulation in the MSFD that GEnS is an expression of the desired condition of the environment.

Background work to define GEnS at individual descriptor level was undertaken by different Task Groups for 10 out of the 11 descriptors (Table 2): biodiversity (Cochrane et al., 2010); nonindigenous species (Olenin et al., 2010); exploited fish (Piet et al., 2010); food-webs (Rogers et al., 2010); human-induced eutrophication (Ferreira et al., 2010); seafloor integrity (Rice et al., 2010); contaminants (Law et al., 2010; Swartenbroux et al., 2010); litter (Galgani et al., 2010) and noise (Tasker et al., 2010). The remaining descriptor, alterations of hydrographical conditions, was addressed in a more general way. For some descriptors, the Task Group report included a clearer definition of GEnS than for others (Table 2). This lack of clarity means that cross-border harmonisation is needed to ensure that environmental status does not change abruptly at the maritime boundary of two states.

The Commission (COM) Decision 2010/477/EU on criteria and methodological standards on Good Environmental Status of marine waters, supported by the documents prepared by the Working Groups, provided a range of criteria and indicators based on which GEnS should be defined. This Decision acknowledges that the application of criteria and identification of indicators should take into account the essential features and characteristics, pressures and impacts identified by MS during the initial assessment of the marine waters (MSFD Article 8, Annex I and III). It gives flexibility for MS to select those criteria and associated indicators that address the most important impacts and threats to a particular marine ecosystem. It also allows for the use of limited criteria/ indicators across a wide marine area, leaving the application of additional criteria/indicators to specific subareas. Consequently, we emphasise that the central task for implementing the MSFD is to determine how the many different criteria/indicators should be combined into an integrative assessment framework.

Although the latest available Common Understanding document (Claussen et al., 2011), drafted by a group assigned to develop a common understanding of the main normative concepts of the MSFD, mentions that "assessments following the first MSFD cycle should move towards full consideration of the relevant criteria and indicators as laid down in COM Decision 2010/477/EU", it is still unclear if this requires 'full' use of the criteria and indicators as laid down in the COM Decision or only those 'relevant' to each marine region. This ambiguity is likely to lead to different approaches (and hence possible confusion) within and between MS, and should be accounted for in any proposal for integrating at the level of criteria 
Table 1

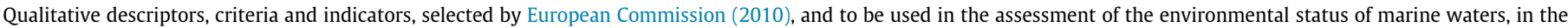
context of the Marine Strategy Framework Directive.

\begin{tabular}{ll}
\hline Descriptor & Criteria \\
\hline $\begin{array}{l}\text { 1. Biological } \\
\text { diversity }\end{array}$ & 1.1. Species distribution \\
& $\begin{array}{l}\text { 1.2. Population size } \\
\text { 1.3. Population condition }\end{array}$ \\
1.4. Habitat distribution \\
1.5. Habitat extent \\
1.6. Habitat condition \\
1.7. Ecosystem structure \\
2.1. Abundance and state of non-indigenous \\
species, in particular invasive species \\
2.2. Environmental impact of invasive non- \\
indigenous sp \\
3.1. Level of pressure of the fishing activity \\
3. Exploited fish
\end{tabular}

4. Food webs

4.1. Productivity of key species or trophic groups

4.2. Proportion of selected species at the top of food webs

4.3. Abundance/distribution of key trophic groups/species

5. Human-induced

5.1. Nutrients levels eutrophication

5.2. Direct effects of nutrient enrichment

Indicator

1.1.1. Distributional range

1.1.2. Distributional pattern within the latter

1.1.3. Area covered by the species (for sessile/benthic species)

1.2.1. Population abundance and/or biomass

1.3.1. Population demographic characteristics

1.3.2. Population genetic structure

1.4.1. Distributional range

1.4.2. Distributional pattern

1.5.1. Habitat area

1.5.2. Habitat volume, where relevant

1.6.1. Condition of the typical species and communities

1.6.2. Relative abundance and/or biomass, as appropriate

1.6.3. Physical, hydrological and chemical conditions

1.7.1. Composition and relative proportions of ecosystem components (habitats, species)

2.1.1. Trends in abundance, temporal occurrence and spatial distribution of non-indigenous species

2.2.1. Ratio between invasive non-indigenous species and native species

2.2.2. Impacts of non-indigenous invasive species at the level of species, habitats and ecosystem

3.1.1. Fishing mortality (F)

3.1.2. Catch/biomass ratio

3.2.1. Spawning Stock Biomass (SSB)

3.2.2. Biomass indices

3.3.1. Proportion of fish larger than the mean size of first sexual maturation

3.3.2. Mean maximum length across all species found in research vessel surveys

3.3.3. 95\% percentile of the fish length distribution observed in research vessel surveys

3.3.4. Size at first sexual maturation

4.1.1. Performance of key predator species using their production per unit biomass

4.2.1. Large fish (by weight)

4.3.1. Abundance trends of functionally important selected groups/species

5.1.1. Nutrients concentration in the water column

5.1.2. Nutrient ratios (silica, nitrogen and phosphorus)

5.2.1. Chlorophyll concentration in the water column

5.2.2. Water transparency related to increase in suspended algae

5.2.3. Abundance of opportunistic macroalgae

5.2.4. Species shift in floristic composition such as diatom to flagellate ratio, benthic to pelagic shifts, as well as bloom events of nuisance/toxic algal blooms caused by human activities

5.3. Indirect effects of nutrient enrichment

5.3.1. Abundance of perennial seaweeds and seagrasses impacted by decrease in water transparency

5.3.2. Dissolved oxygen changes and size of the area concerned

6.1.1. Type, abundance, biomass and areal extent of relevant biogenic substrate

6.1.2. Extent of the seabed significantly affected by human activities for the different substrate types

6.2.1. Presence of particularly sensitive and/or tolerant species

6.2.2. Multi-metric indices assessing benthic community condition and functionality, such as species diversity and richness, proportion of opportunistic to sensitive species

6.2.3. Proportion of biomass or number of individuals in the macrobenthos above specified length/size

6.2.4. Parameters describing the characteristics of the size spectrum of the benthic community

7. Hydrographical

7.1. Spatial characterisation of permanent conditions

7.2. Impact of permanent hydrographical changes

8. Contaminants

8.1. Concentration of contaminants

8.2. Effects of contaminants

9. Contaminants in fish and seafood

9.1. Levels, number and frequency of contaminants

\subsubsection{Extent of area affected by permanent alterations}

7.2.1. Spatial extent of habitats affected by the permanent alteration

7.2.2. Changes in habitats, in particular the functions provided due to altered hydrographical conditions

8.1.1. Concentration of the contaminants measured in matrices such as biota, sediment and water

8.2.1. Levels of pollution effects on the ecosystem components concerned, having regard to the selected biological processes and taxonomic groups where a cause/effect relationship has been established

8.2.2. Occurrence, origin, extent of significant acute pollution events and their impact on biota physically affected by this pollution

9.1.1. Actual levels of contaminants that have been detected and number of contaminants which have exceeded maximum regulatory levels

9.1.2. Frequency of regulatory levels being exceeded 
Table 1 (continued)

\begin{tabular}{|c|c|c|}
\hline Descriptor & Criteria & Indicator \\
\hline \multirow[t]{3}{*}{ 10. Litter } & $\begin{array}{l}\text { 10.1. Characteristics of litter in the marine and } \\
\text { coastal environment }\end{array}$ & $\begin{array}{l}\text { 10.1.1. Trends in the amount of litter washed ashore and/or deposited on coastlines, including } \\
\text { analysis of its composition, spatial distribution and source }\end{array}$ \\
\hline & & $\begin{array}{l}\text { 10.1.2. Trends in the amount of litter in the water column and deposited on the seafloor } \\
\text { 10.1.3. Trends in the amount, distribution and composition of micro-particles }\end{array}$ \\
\hline & 10.2. Impacts of litter on marine life & 10.2.1. Trends in the amount and composition of litter ingested by marine animals \\
\hline \multirow[t]{2}{*}{$\begin{array}{l}\text { 11. Energy and } \\
\text { noise }\end{array}$} & $\begin{array}{l}\text { 11.1. Distribution in time and place of loud, low } \\
\text { and mid frequency impulsive sounds }\end{array}$ & $\begin{array}{l}\text { 11.1.1. Proportion of days and their distribution within a calendar year over areas of a } \\
\text { determined surface, as well as their spatial distribution, in which anthropogenic sound sources } \\
\text { exceed levels that are likely to entail significant impact }\end{array}$ \\
\hline & 11.2. Continuous low frequency sound & $\begin{array}{l}\text { 11.2.1. Trends in the ambient noise level within the } 1 / 3 \text { octave bands } 63 \text { and } 125 \mathrm{~Hz} \text { (centre } \\
\text { frequency) measured by observation stations and/or with the use of models }\end{array}$ \\
\hline
\end{tabular}

and indicators. Therefore, although the choice of criteria/indicators and aggregation rules are the responsibility of MS, coherence of frameworks within the different marine regions or sub-regions and across the Community should be ensured. Accordingly, we question whether minimum requirements should be proposed, and if so, at which level should those minima be set: indicators, criteria or descriptors.

\section{The role of setting targets in quantifying Good Environmental Status}

After agreeing on what to include for definition of GEnS, the next question, if we are to implement it, would be: on which level do we define it and how do we quantify it? The MS Initial Assessments (available at http://cdr.eionet.europa.eu/recent_etc?RA_ID=608) made it clear that these were ambiguous steps, since both GEnS and Environmental Targets have been defined and set at different levels across MS, from descriptor level to indicator level. Hence, we question the implications of this for GEnS comparability.

Many environmental initiatives worldwide, and especially European Directives, have the fundamental requirement for an authority to determine whether an area/ecological component/ habitat is as expected given the prevailing environmental conditions and, if not and the changes are due to human activities, then which actions are required to remediate any problems. Hence, assessing the current environmental status requires a comparison between an expected/usual/normal state and an impacted one. Thus, it is necessary to determine a reference/baseline/threshold/ trigger condition against which the actual or potentially changed situation can be compared (Borja et al., 2012). Therefore by definition, the determination of good status implies a condition which has been or can be compared against that anthropogenically-altered state. For example, the WFD indicates that there are four ways of determining that reference condition: (i) to find an area similar to the one under study, but without the pressures (de facto, a control area); (ii) to hindcast to a time before pressures exerted an influence; (iii) to numerically model an unimpacted condition for comparison, and, if none of these are possible, (iv) to use expert judgement (Hering et al., 2010). Each of these alternatives poses challenges: (i) the unavailability or difficulty of finding unimpacted conditions, especially in the highly developed areas or within ecoregions; (ii) the question of the baseline conditions for hindcasting (and the basis that some unimpacted prior utopia may be unattainable); (iii) the uncertainty or unavailability of numerical models for unbounded marine areas or moving baselines (caused by climate change), and (iv) the perceived reluctance to rely on expert judgement if there is the likelihood of any legal challenge to management mechanisms such as sanctions to industries likely to impact an area (Duarte et al., 2009; Carstensen et al., 2011; Borja et al., 2012).

It is axiomatic that 'you cannot manage without measurement' and so numerical targets are central in determining whether MS succeed or fail to attain GEnS (Borja et al., 2012). The description of GEnS and the establishment of environmental targets (under Articles 9 and 10 of the MSFD, respectively) need a clear understanding for making this GEnS assessment operational. Claussen et al. (2011) suggest that the MSFD depends on measurable environmental targets and thus is linked to relevant indicators. Furthermore, they expect that the indicators and environmental targets will be related to the 11 descriptors and thus directly linked to the marine environmental pressures as indicated in the Annex III of the MSFD. Most importantly they suggest that "... to articulate quantitatively what GES looks like and/or set appropriate environmental targets it will be necessary to define for each of the criteria and, where appropriate, the indicators in COM Decision 2010/477/EU, environmental boundaries or thresholds above or below which GES is considered to have been met. ... To that effect, a boundary between success and failure to achieve or maintain GES should be established. Thresholds/levels/limits in this sense represent that boundary between an acceptable and unacceptable status".

These comments indicate the central problem being addressed here - that in the discussions of the Common Implementation Strategy of the MSFD, GEnS is still contemplated as a combination, as yet undefined, of indicators, targets, thresholds, levels, limits, criteria, and descriptors. Hence, we need to question whether these "environmental thresholds/levels/limits" are equivalent to environmental targets and, if so, does this mean we would have GEnS/ non-GEnS at indicator level. It is therefore necessary to clarify whether an 'Environmental Target', as described in Art.10 of the MSFD, is equivalent to an 'Environmental threshold/level/limit' proposed at the level of indicators to make them operational by monitoring the changes in attributes (Claussen et al., 2011). Furthermore, if they are, how do these environmental targets at the indicator level relate to a broader GEnS description for any given marine region? Annex IV of the MSFD presents the term Environmental Target as a far more complex and integrative concept (Fig. 1) that is unlikely to be set at the indicator level or informed effectively by a single indicator.

Claussen et al. (2011) recognise four types of environmental targets: pressure-, state-, impact-based- and operational targets whose adequacy is largely dependent on the robustness of the evidence available and the nature of any descriptor. However, their examples indicate that the type of targets differ essentially according to how the target is expressed (as state indicators, identified pressures, or impacts on biodiversity components) rather than in the approaches used to measure achievement of targets (see examples in Claussen et al., 2011).

\section{Integration of the assessments: from indicator level up to the level of GEnS}

After setting reference values for the indicators, and determining the status of individual indicators and descriptors, a new problem emerges when attempting to integrate all this information into a unique status assessment. Whereas the WFD uses the so-called 
Table 2

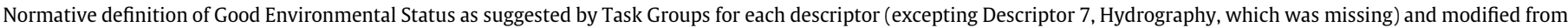

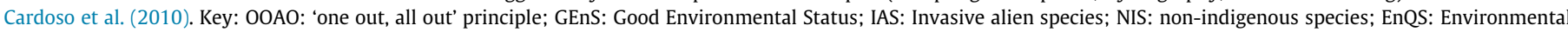
Quality Standards; MSFD: Marine Strategy Framework Directive.

\begin{tabular}{|c|c|}
\hline Descriptor & Good Environmental Status definition \\
\hline 1. Biological diversity & $\begin{array}{l}\text { GEnS will be achieved if there is no further loss of the diversity of genes, species and } \\
\text { habitats/communities at ecologically relevant scales and when deteriorated } \\
\text { components, where intrinsic environmental conditions allow, are restored to target } \\
\text { levels. Target levels are defined as being such that "the quality and occurrence of } \\
\text { habitats and the distribution and abundance of species are in line with prevailing } \\
\text { physiographic, geographic and climatic conditions". Some deviation from reference } \\
\text { conditions, as a result of human use of the marine environment, is acceptable, } \\
\text { providing the terms of the Descriptor are still met }\end{array}$ \\
\hline
\end{tabular}

2. Non-indigenous species IAS cause adverse effects on environmental quality resulting from changes in biological, chemical and physical properties of aquatic ecosystems. These changes include, but are not limited to: elimination or extinction of sensitive and/or rare populations; alteration of native communities; algal blooms; modification of substrate conditions and the shore zones; alteration of oxygen and nutrient content, $\mathrm{pH}$ and transparency of water; accumulation of synthetic pollutants, etc. The magnitude of impacts may vary from low to massive and they can be sporadic, shortterm or permanent. The degradation gradient in relation to NIS is a function of their relative abundances and distribution ranges, which may vary from low abundances in one locality with no measurable adverse effects up to occurrence in high numbers in many localities, causing massive impact on native communities, habitats and ecosystem functioning

3. Exploited fish and shellfish

4. Food webs

5. Human-induced eutrophication

6. Seafloor integrity

8. Contaminants

9. Contaminants in fish and seafood

10. Litter

11. Energy and noise
Since there is broad scientific evidence that GEnS cannot be achieved for all stocks simultaneously, a realistic threshold for the proportion of stocks with GEnS needs to be established above which the descriptor has achieved GEnS

GEnS should ensure that populations of selected food web components occur at levels that are within acceptable ranges that will secure their long-term viability

GEnS has been achieved when the biological community remains well-balanced and retains all necessary functions in the absence of undesirable disturbance associated with eutrophication (e.g. excessive algal blooms, low dissolved oxygen, declines in seagrasses, kills of benthic organisms and/or fish) and/or where there are no nutrient-related impacts on sustainable use of ecosystem goods and services

The standard for GEnS should reflect the goals for management of the impacts of human activities on the sea floor. It is explicit in the definition of the descriptor that human uses of the ocean, including uses that affect the sea floor, are consistent with the MSFD, as long as those uses are sustainable. Sustainability is achieved when the pressures associated with all those uses cumulatively do not hinder the ecosystem components to retain their natural diversity, productivity and dynamic ecological processes. Perturbations due to use must be small enough that recovery is rapid and secure if a use ceases

Achievement of EnQS. Biological effects should be assessed against threshold levels of response that are indicative of significant harm to the organisms concerned

GEnS would be achieved if all contaminants are at levels below the levels established for human consumption or showing a downward trend (for the substances for which monitoring is ongoing but for which levels have not yet been set). However, it is generally felt that GEnS for descriptor 9 must be judged in view out the monitoring of descriptor 8, also dealing with contaminants in marine environment

Definitions of the acceptable levels of harm and GEnS must consider impacts as assessed by the amount of litter in different compartments of the marine environment (seabed, sea surface, water column, coastline), ecological effects of the litter (e.g. plastics ingested by marine organisms; entanglement rates) and problems associated with degradation of litter (microparticles) as well as social and economic aspects. Tourism is strongly negatively affected by the presence of litter. An overriding objective will be a measurable and significant decrease (e.g. 10\%/year for litter on coastlines) in the total amount of litter in the environment by 2020

GEnS occurs when there is no adverse effect of energy inputs on any component of the marine environment. However, such an objective is probably not achievable if, for instance, behavioural disturbance or mortality of plankton (including planktonic larvae) is considered an adverse effect. Such an objective is probably not also measurable for a very large proportion of organisms in the marine environment
Aggregation rules

GEnS will be achieved when each of the targets established by the Member States for all the attributes and components of biological diversity have been met (OOAO)

Methods for aggregating indicators for GEnS assessments need to take into account the known IAS effects in other world regions or in neighbouring areas

GEnS is achieved for a particular stock only if criteria for all attributes are fulfilled (OOAO)

GEnS will therefore be achieved when the indicators describing the various attributes of the descriptor reach the thresholds set for them (OOAO)

No specific method is recommended, but those used must be robust, integrated, sufficiently sensitive, comparable, and with recognised scientific merit

No single algorithm for combining indicator values will be appropriate for evaluating GEnS or providing a meaningful index of GEnS. It may be possible to conduct such analytical syntheses of Indicators for individual attributes on local scales. However, across attributes and on even moderate scales expert assessments rather than algorithmic formulae will be needed for evaluation

Integration is greatly facilitated by coherent and consistent sets of assessment thresholds (EnQS)

OOAO

No proposal 


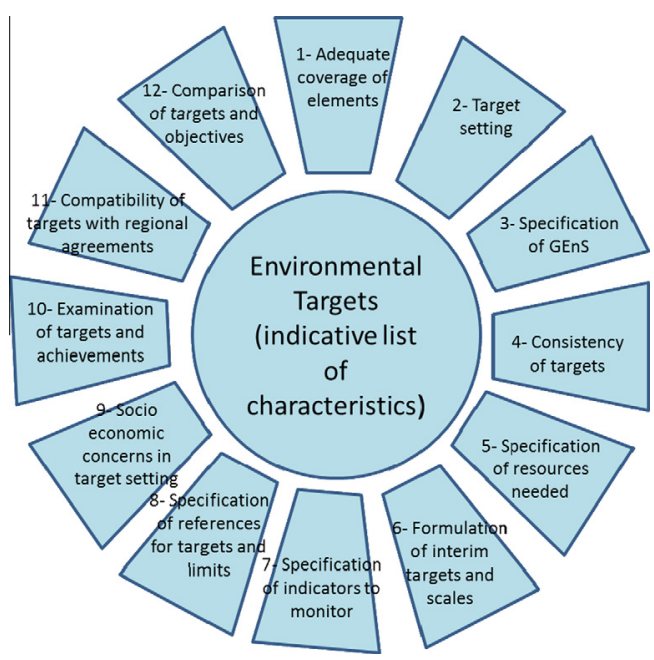

Fig. 1. The indicative list of 12 characteristics of environmental targets as outlined in Annex IV Marine Strategy Framework Directive (modified from Claussen et al. (2011)).

weighting of the different indicators and descriptors (Borja et al., 2010). It implies that recombining a set of structural attributes gives an accurate representation of the ecosystem functioning.

Our detailed analysis of the work carried out by the descriptorspecific working groups suggests there has been a lot of initial activity, but little attention was paid to how the data/information will eventually be used. Despite their importance, combination rules for the MSFD descriptors and indicators were excluded from the remit of the Task Groups; in our view, an omission which needs to be addressed. For example, if the OOAO principle was to be applied to the 11 descriptors and 56 indicators, the probability to fail one or more indicators, even through analytical error, would be very high at any studied location, as demonstrated for the WFD with fewer components, the 5 biological quality elements (Borja and Rodríguez, 2010). This is especially problematical when different elements address the same pressure (Caroni et al., 2013) which, if both are combined, leads to 'double-counting' and thus an overemphasis on the resulting status. Although Annex 1 of the MSFD describes the GEnS individually for each of the 11 descriptors, this does not imply the ability to have GEnS at the level of all the descriptors, nor does it mean that each descriptor should necessarily be graded individually in a binary way (i.e. good or not Good Environmental Status). For example, the HELCOM (2010) tool for assessment of 'ecosystem health' (in practice equivalent to GEnS) groups indicators into 3 categories: biology, hazardous substances, and supporting indicators; applying then the OOAO rule at the 3 category level. Hence, reducing the MSFD descriptors to 3 groups, and then using the OOAO approach for those groups, may be a pragmatic compromise which minimises the probability of failure, due to analytical errors or statistical chance, while still giving one overall assessment of GEnS. This is analogous to the Environmental Integrative Indicator (EII) approach of Aubry and Elliott (2006) in which 27 indicators were grouped and weighted into 3 EII.

The integration issue is further complicated by the fact that some of the descriptors function as pressures for other descriptors; e.g. alien species can be a threat to biodiversity and food web functioning; alterations in the hydrological regime can be a threat to seafloor integrity. Thus, we suggest that the 11 descriptors are hierarchical and do not have an equal weighting when assessing the overall GEnS (Borja et al., 2010). We further suggest that we take the philosophical view that for the descriptor Biodiversity to be fulfilled requires all others to be met and similarly if one of the stressor or pressure-related descriptors (e.g. energy including noise) fails then by definition the biodiversity will be adversely affected.

In addition to this problem of aggregating indicators and descriptors, whilst the WFD centres on quality assessments within a small area, albeit extrapolated to a water body (Hering et al., 2010), the MSFD requires MS to integrate and geographically scale-up the assessments, at the level of an eco-region (Borja et al., 2010). This means that the GEnS assessments of the MS need to be comparable in order to enable integrating their assessments into an ecoregion-wide assessment and to avoid cross-border anomalies. This requires that comparable methods and aggregation rules are needed to ensure minimum standards for GEnS reporting across MS and as such we advocate a set of common principles (expanded from Claussen et al., 2011):

(i) The integration across levels of different complexity should accommodate different alternatives, i.e., integration below descriptor level (across indicators within criteria, and criteria within descriptors) could certainly differ from descriptor level integration (see Table 3, for different options at this level);

(ii) Integrate across state descriptors (D1, D3, D4, D6) differently than across pressure descriptors (D2, D5, D7, D8, D9, D10, D11) (see Table 1, for identification);

(iii) Consider a different contribution of the two types of main Descriptors for the overall GEnS evaluation - giving state descriptors a higher weight, as receptors of the impacts produced by pressures. The rationale for this, as recognised by Claussen et al. (2011), is that "in principle, where GEnS for state-based descriptors (D1, 3, 4, 6) are achieved it follows that GEnS for pressure-based descriptors should also be met"; this makes the assumption that if the state is satisfactory then the pressures must be having a limited (or mitigated) impact.

Independently of which aggregation proposal(s) is adopted and at which level, the precautionary principle should always be observed in the absence of more robust knowledge.

\section{Proposal of an operational definition of GEnS}

Elliott (2011) suggested that the only main aim in marine management is to protect and maintain the natural ecological functioning and at the same time deliver the benefits for society (based on ecosystem services and societal benefits) - this is de facto the Ecosystem Approach. Hence, we suggest that this should be taken as a starting point to define GEnS - in essence that GEnS is achieved if the conservation objectives, the ecosystem services and the societal benefits are delivered sustainably. If this is accepted then the challenge is to make this operational and indicate how it can be linked to monitoring, management and spatial planning.

The essence of the GEnS concept is to determine what type of ecological change is possible as the result of human pressures. If the primary aim is to ensure 'healthy, productive and safe seas' then we could use the 7 indicators for general application for the diagnosis of ecosystem pathology proposed by Harding (1992); see also Elliott (2011): primary production, nutrients, species diversity and abiotic zones, instability and biotic composition, disease prevalence, size spectrum, bioaccumulation (and effects) of contaminants. Hence, an adverse change in any of these indicates a deviation from GEnS and thus a reduction in health of the system (see Tett et al., in press) - thus equating GEnS with 'healthy'. This also implies that a healthy system is robust to the effects of stressors (Tett et al., in press; Mouillot et al., 2013). 
Table 3

Options for determining if an area/regional sea is in Good Environmental Status. Key: OOAO: 'one out, all out' principle.

\begin{tabular}{|c|c|c|c|c|c|}
\hline Option & Decision rule & Data requirements & Pros & Cons & Examples in place \\
\hline $\begin{array}{l}\text { Either: } 1 . \text { Fulfilling all the } \\
\text { indicators in all the } \\
\text { descriptors }\end{array}$ & $\begin{array}{l}\text { All indicators are } \\
\text { met irrespective of } \\
\text { weighting (OOAO) }\end{array}$ & $\begin{array}{l}\text { Data needed for all } \\
\text { aspects on regional } \\
\text { seas scale }\end{array}$ & $\begin{array}{l}\text { Most } \\
\text { comprehensive } \\
\text { approach }\end{array}$ & $\begin{array}{l}\text { Unreasonable data } \\
\text { requirements; all areas will fail } \\
\text { on at least one indicator; may } \\
\text { include double-counting }\end{array}$ & None \\
\hline $\begin{array}{l}\text { Or: } 2 \text {. Fulfilling the indicators in } \\
\text { all descriptors but as a } \\
\text { weighted list according to } \\
\text { the hierarchy of the } \\
\text { descriptors }\end{array}$ & $\begin{array}{l}\text { Agreeing the } \\
\text { weighting }\end{array}$ & $\begin{array}{l}\text { Data needed for all } \\
\text { aspects on regional } \\
\text { seas scale }\end{array}$ & $\begin{array}{l}\text { Reflects the } \\
\text { interlinked nature } \\
\text { of the descriptors } \\
\text { and avoids double } \\
\text { counting }\end{array}$ & $\begin{array}{l}\text { Unreasonable data } \\
\text { requirements; problem of } \\
\text { agreeing the weighting }\end{array}$ & $\begin{array}{l}\text { HELCOM (2010), Borja } \\
\text { et al. (2011), Aubry and } \\
\text { Elliott (2006) }\end{array}$ \\
\hline $\begin{array}{l}\text { Or: } 3 \text {. Fulfilling the indicators } \\
\text { just for the biodiversity } \\
\text { descriptor and making sure } \\
\text { these encompass all other } \\
\text { quality changes }\end{array}$ & $\begin{array}{l}\text { All biodiversity } \\
\text { indicators are met } \\
\text { irrespective of } \\
\text { weighting }\end{array}$ & $\begin{array}{l}\text { Data needed for all } \\
\text { components of } \\
\text { biodiversity }\end{array}$ & $\begin{array}{l}\text { Focuses on the } \\
\text { main aspect }\end{array}$ & $\begin{array}{l}\text { Assumes that the biodiversity } \\
\text { descriptor really does } \\
\text { encompass all others }\end{array}$ & None \\
\hline $\begin{array}{l}\text { Or: } 4 \text {. Create a synthesis } \\
\text { indicator which takes the } \\
\text { view that 'GEnS is the ability } \\
\text { of an area to support } \\
\text { ecosystem services, produce } \\
\text { societal benefits and still } \\
\text { maintain and protect the } \\
\text { conservation features' }\end{array}$ & $\begin{array}{l}\text { Integration of the } \\
\text { information from } \\
\text { different descriptors } \\
\text { and indicators, and } \\
\text { evaluation of the } \\
\text { overall benefits }\end{array}$ & $\begin{array}{l}\text { Data needed for the } \\
\text { indicators included in } \\
\text { that synthesis } \\
\text { indicator, valuation of } \\
\text { the ecosystem } \\
\text { services and benefits }\end{array}$ & $\begin{array}{l}\text { Fulfils the main } \\
\text { aim of marine } \\
\text { management (see } \\
\text { text) }\end{array}$ & $\begin{array}{l}\text { Requires a new indicator and an } \\
\text { agreement in the way of } \\
\text { integrate the information; } \\
\text { trade-offs between ecosystem } \\
\text { services and their beneficiaries } \\
\text { require either economic, ethical } \\
\text { or political evaluation and } \\
\text { decision, and cannot be based } \\
\text { only on ecological knowledge }\end{array}$ & Borja et al. (2011) \\
\hline $\begin{array}{l}\text { Or: } 5 \text {. Have a check-list (ticking } \\
\text { boxes) of all the aspects } \\
\text { needed }\end{array}$ & $\begin{array}{l}\text { Then if an area has } \\
\text { e.g. more than } 60 \% \\
\text { of the boxes ticked } \\
\text { then it is in GEnS }\end{array}$ & $\begin{array}{l}\text { An expert judgement } \\
\text { approach, based on } \\
\text { 'probability of } \\
\text { evidence' }\end{array}$ & $\begin{array}{l}\text { It may reflect the } \\
\text { state of the } \\
\text { science; if done } \\
\text { rigorously then it } \\
\text { may be the easiest } \\
\text { to implement }\end{array}$ & $\begin{array}{l}\text { It may be too subjective (i.e. } \\
\text { based on soft intelligence) }\end{array}$ & $\begin{array}{l}\text { Bricker et al. (2003); } \\
\text { Ferreira et al. (2011) }\end{array}$ \\
\hline $\begin{array}{l}\text { Or: } 6 \text {. Have a summary diagram } \\
\text { such as a spiders-web } \\
\text { diagram showing the 'shape } \\
\text { of GEnS according to several } \\
\text { headline indicators' }\end{array}$ & $\begin{array}{l}\text { The shape of the } \\
\text { diagram }\end{array}$ & & $\begin{array}{l}\text { Easy to } \\
\text { understand and } \\
\text { show to managers }\end{array}$ & $\begin{array}{l}\text { The decision on when GEnS is } \\
\text { achieved }\end{array}$ & Halpern et al. (2012) \\
\hline $\begin{array}{l}\text { Or: } 7 . \text { Not reporting the } \\
\text { environmental status but } \\
\text { only the list of pressures (i.e. } \\
\text { on the premise that if an area } \\
\text { has no obvious pressures } \\
\text { then any changes in the area } \\
\text { must be due to natural } \\
\text { changes which are outside } \\
\text { the control of management) }\end{array}$ & $\begin{array}{l}\text { No pressures in an } \\
\text { area sufficient to } \\
\text { cause adverse effects }\end{array}$ & $\begin{array}{l}\text { Quantitative maps of } \\
\text { pressures }\end{array}$ & $\begin{array}{l}\text { Can be derived by } \\
\text { national } \\
\text { databases, } \\
\text { mapping, pressure } \\
\text { lists }\end{array}$ & $\begin{array}{l}\text { Relates to 'cause' rather than } \\
\text { 'effect', difficult to set } \\
\text { boundaries between pressure } \\
\text { status classes: is it sufficient to } \\
\text { base the assessment on the list } \\
\text { of pressures, while those can } \\
\text { have very different spatial } \\
\text { extent and strength? }\end{array}$ & $\begin{array}{l}\text { Aubry and Elliott (2006), } \\
\text { Halpern et al. (2008), } \\
\text { Korpinen et al. (2012) See } \\
\text { also Solheim et al. (2012) } \\
\text { for the analysis of WFD } \\
\text { pressures and impacts }\end{array}$ \\
\hline $\begin{array}{l}\text { Or: } 8 . \text { A combination of all/some } \\
\text { of these when there are } \\
\text { insufficient data in some } \\
\text { areas or for some descriptors } \\
\text { or indicators }\end{array}$ & & $\begin{array}{l}\text { Combination of } \\
\text { pressures and } \\
\text { descriptors data }\end{array}$ & $\begin{array}{l}\text { Information } \\
\text { available from } \\
\text { Member States } \\
\text { reports }\end{array}$ & $\begin{array}{l}\text { Either requires too much } \\
\text { information (hence } \\
\text { unreasonable) or too little } \\
\text { (hence inaccurate) }\end{array}$ & None \\
\hline
\end{tabular}

If GEnS is regarded as being synonymous with naturally 'productive' then we need to include the unifying currency for determining whether the marine system is delivering what society wants (an anthropocentric view) (Atkins et al., 2011a,b). That is, whether the seas are maintaining the ecosystem services and delivering societal benefits (in a sustainable way). For example, if the marine system delivers the relevant ecosystem services without compromising the natural ecosystem functioning then is that sufficient to say an area is achieving GEnS? There can be also trade-offs between ecosystem services: for example, a cold-water coral reef can provide high value for the 'regulation and maintenance service' by for example providing the nursery function for some fish species, and at the same time the 'provisioning service', the capture of wild fish of other species is decreasing because of a legal regulation (e.g. establishment of Marine Protected Area, or closure for deep water fisheries) (Foley et al., 2010). In such cases, there is the need to identify beneficiaries, and to evaluate how society, as a whole, would benefit from protecting the reef. If only economic use values were used then this emphasise an anthropocentric definition of GEnS, as above (i.e. 'seas are maintaining the ecosystem services and delivering societal benefits in a sustainable way') but we also have to incorporate the non-use values (Atkins et al., 2011a). In addition, this has to encompass the intrinsic conservation value, i.e. the value of the ecosystem for its own sake (Pascual et al., 2012).

We consider that the definition (or definitions) of GEnS not only has (or have) to summarise the status but that they have to be able to be used in real-time assessments and the operational management of the marine system. Therefore, the operational GEnS definition that we propose is: "GEnS is achieved when physico-chemical (including contaminants, litter and noise) and hydrographical conditions are maintained at a level where the structuring components of the ecosystem are present and functioning, enabling the system to be resistant (ability to withstand stress) and resilient (ability to recover after a stressor) to harmful effects of human pressures/activities/impacts, where they maintain and provide the ecosystem 
services that deliver societal benefits in a sustainable way (i.e. that pressures associated with uses cumulatively do not hinder the ecosystem components in order to retain their natural diversity, productivity and dynamic ecological processes, and where recovery is rapid and sustained if a use ceases)".

The main challenge is to translate this definition into terms suitable to provide an operational tool. Based on the previous section (integration of the assessments), we propose that there are at least 8 options to determine the GEnS in a regional sea context (Table 3). Hence, we detail the concept behind the options, then select the decision rule for the method to be implemented, consider what type and amount of data are required, and then consider the pros and cons of the different options. The options from 1 to 8 are sequentially less demanding of new data, and the degree of detailed ecological assessment. As such, Option 1, which is most similar to the WFD approach, deconstructs GEnS into the 11 descriptors and then into the component indicators, assessing each for each area before attempting to produce an overall assessment (Table 3). However, having a complete dataset covering all descriptors and indicators for the assessment is difficult, and the use of pressure maps as a proxy of the status and impacts to marine ecosystems could be considered (Aubry and Elliott, 2006; Halpern et al., 2008; Korpinen et al., 2012). Option 7, in contrast, only uses published data for the activities, and then infers a relationship between activity, pressures and impacts both on the natural and anthropogenic system. Between these extremes, there are several options to integrate and present information (see Borja et al., 2011; Halpern et al., 2012), each with its own requirements, pros and cons (Table 3). Most of the options have been used in quality assessments of estuaries, lagoons, coastal and marine areas (see Table 3 references).

Determining the quality of any ecological element (individual, community, population or ecosystem), in relation to single or combined pressures and accounting for the inherent variability in the system is expensive and, in the current economic climate, this may be prohibitive (Borja and Elliott, 2013). Therefore, as suggested with Option 7, it is likely to be easier and cheaper to determine the GEnS as the 'absence of pressures' in a region rather than the 'presence of good environment'. The former has been used to good effect to create Quality Status Reports from OSPAR (2010) and HELCOM (2010) and can be obtained from maps and aerial photos, databases of users, automatic measuring such as Vessel Monitoring Systems (VMS) in the open sea, and limited modelling exercises. In contrast, detecting the 'presence of a good environment' requires a large amount of monitoring, i.e. each ecological and physical component needs to be assessed for its 'goodness', in itself a human (and thus subjective) construct (Mee et al., 2008). Despite this, detecting severe impacts is straightforward. However, in most seas surrounding developed countries, these impacts are likely to be on a small scale and/or produced by pointsource pressures and thus controlled by licensing. This leads to a problem of whether to judge the quality of a sea area according to the many pressures which may each only affect a small area and cumulatively affect a small proportion of a sea area but still resulting in a label of 'Poor Environmental Status'. Also this would require agreeing a pressure classification and indices that can show the strength and spatial extent of, and time for exposure to the pressure (e.g. using a pressure classification: low pressure, medium pressure, high pressure). For instance, based on the WFD pressure data reported by MS, it is possible to present the percentage of all classified water bodies affected by certain types of pressures (Solheim et al., 2012). The pressures included in the assessment are point and/or diffuse pollution per marine region, hydro-morphological pressures and/or altered habitats per marine region. However, the intensity and extent of different pressures is not evaluated - only presence or absence. As an example, the Baltic
Sea Pressure Index (Korpinen et al., 2012) provides a dimensionless value of the indicator with a gradient from an absence of pressures to cases (areas) where virtually almost all pressures are present. However, the problem of boundary setting still remains including how to determine what is good and what is not good (Mee et al., 2008). One danger of focussing on pressures is that many are point-source in nature and so trying to extrapolate to whole ecoregions and sub-regions, as required by the MSFD, is difficult. Furthermore, diffuse sources may be difficult to identify and tackle, especially if having a trans-boundary effect.

Option 5, suggesting the use of a tick-list approach, takes a quasi-legal approach based on the probability of evidence, some or much of which may be based on informed judgement or based on precedent elsewhere. For example, even if there are insufficient data for all aspects, if the qualitative trends (even using expert judgement) in many of the aspects all point to an area being in good status then by definition the area is in good status (Ferreira et al., 2011). This probability of evidence approach is used in common law (i.e. as the best available evidence) and was the approach taken by Bricker et al. (2003) to rigorously take 'soft intelligence' from many US estuaries relating to eutrophication effects and combine this to form 'hard data', hence producing an assessment which had the confidence of managers and stakeholders alike.

By definition, because of the way the MSFD has been constructed, GEnS requires a multi-metric approach which can accommodate or encompass the descriptors and component indicators/ criteria. As suggested by Option 6, a bottom-up approach whereby each is assessed and combined either numerically or, for example, as an 'amoeba-type' representation (Ten Brink et al., 1991), would be of value. Although such a diagram, encompassing the descriptors, criteria and indicators, has not yet been constructed, it is expected that it would indicate some kind of ecosystem 'deformation' from a circle or polygon or even the Ocean Health Index by Halpern et al. (2012). It is especially important to incorporate and quantify the pressure and resilience directly into an assessment, although this is always one of the most difficult aspects to achieve, assuming this direct linkage and accounting for these "un-measurable" aspects.

The application of an operational definition of GEnS, such as that proposed before, implies many challenges. Firstly, the current economic difficulties may preclude an appropriate amount of monitoring to be carried out if any determination of GEnS requires assessments for all descriptors and for all components and indicators of those descriptors in all areas. Hence, the MSFD requires flexibility in selecting the most relevant indicators and criteria. De Jonge et al. (2006) consider the problems of marine monitoring against changing political imperatives, where the successive revision of monitoring programmes usually equates to reductions, and Borja and Elliott (2013) consider the problem of a lack of funding for monitoring and thus the potential threat of uninformed marine decision-making. For example, the Danish national monitoring programme was initiated in 1989 to follow responses in the aquatic environment to nutrient reduction plans adopted in 1987 (Carstensen et al., 2006). This monitoring programme was ambitious from the outset but revisions have gradually reduced monitoring efforts, and for the first WFD planning period (20092015) and with the start of the MSFD monitoring (from 2014), the sampling effort is at its lowest for more than two decades. Thus, we are concerned that the information base on which decision-making should be made, potentially with large economic consequences, is gradually eroding due to reduced budgets for marine monitoring.

Secondly, it is questioned whether there should be a continuing emphasis on the physical and chemical approach against a prevailing desire (and philosophy) to monitor ecological health. If there are accepted links between deterioration in physical and chemical 
parameters and the reduction in ecological health then the former parameters can be used as a proxy for the latter and may be easier to monitor. However, if such links are not reliable then the more complex and expensive ecological monitoring will be required. This also relates to the difficulty of determining and implementing what is meant by pass and fail in an operational context, especially against a background of high variability in all aspects of the biological, physical and chemical system in the marine environment. The high variability may require ecologists to acknowledge that some of the components cannot be used operationally in monitoring for Good Environmental Status, for example, trying to determine if a low and highly variable abundance of a marine mammal conforms to an accepted level. Hence, as suggested above, it may be easier to determine 'an absence of pressures' rather than a 'presence of good physical, chemical and biological features' and rely on adequate, remotely collected data and information.

In addition, further research is required to determine the relative merits of measuring each ecological component, which are surrogates or proxies for others, in which case is it better and more cost-effective to measure an absence of pressures rather than a presence of good ecology, and which components are most suitable and cost-effective to assess which pressure effects.

Thirdly, there are spatial considerations and anomalies including the problems created by the overlap in space of the WFD, MSFD, Habitats Directive and the proposed Maritime Spatial Planning and Integrated Coastal Management Directive, as well as the Common Fisheries Policy. This also needs consideration of which piece of legislation takes precedence in an area and so whether the definitions of 'good status', GEnS, GEcS or FCS (Favourable Conservation Status, under the Habitats Directive), are in agreement. It has been suggested that the WFD takes precedence in the nearshore area and the Habitats Directive in designated areas of conservation. However, there are likely to be spatial anomalies in the proposed system whereby marine areas may fail under GEnS and yet still be given the status as Special Protection Areas (SPA) and Special Areas for Conservation (SAC), under the Habitats and Wild Birds Directives.

\section{Concluding remarks and recommendations}

As discussed here: (i) marine management governance initiatives have to deal with the complexity of the marine and adjoining systems and thus the initiatives become complex in themselves, as with the WFD (Hering et al., 2010); (ii) there is a plethora of such mechanisms such as the Regional Seas Conventions (such as OSPAR, HELCOM), which have been assessing and advising on marine areas since the 1970s, and (iii) it is recognised that there is limited funding for large-scale data gathering exercises. Hence, we advocate that the means of implementing the MSFD have to be simpler than the WFD, to be based on the work of the Regional Seas Conventions and as much as possible be based on existing datasets.

Above we propose an operational definition of GEnS and, based on the collective experience of the authors, hope that this can be accepted even after being refined as necessary. In order to be accepted there is the need to show that such a definition encompasses all descriptors and their criteria, and that we are aware of the data and information required (and either existing or which can be obtained) to ensure the definition is met (see Fig. 2). We have made a preliminary attempt at this in Table 4 . This shows that whereas we have some data covering the regional seas, we have many data based on pressures within small areas and so any large scale assessment will have to be derived by combining such data. Hence, it illustrates the fundamental challenge of arriving at a regional quality status either by having a broad approach and omitting or down-weighting point-source problems or summing the

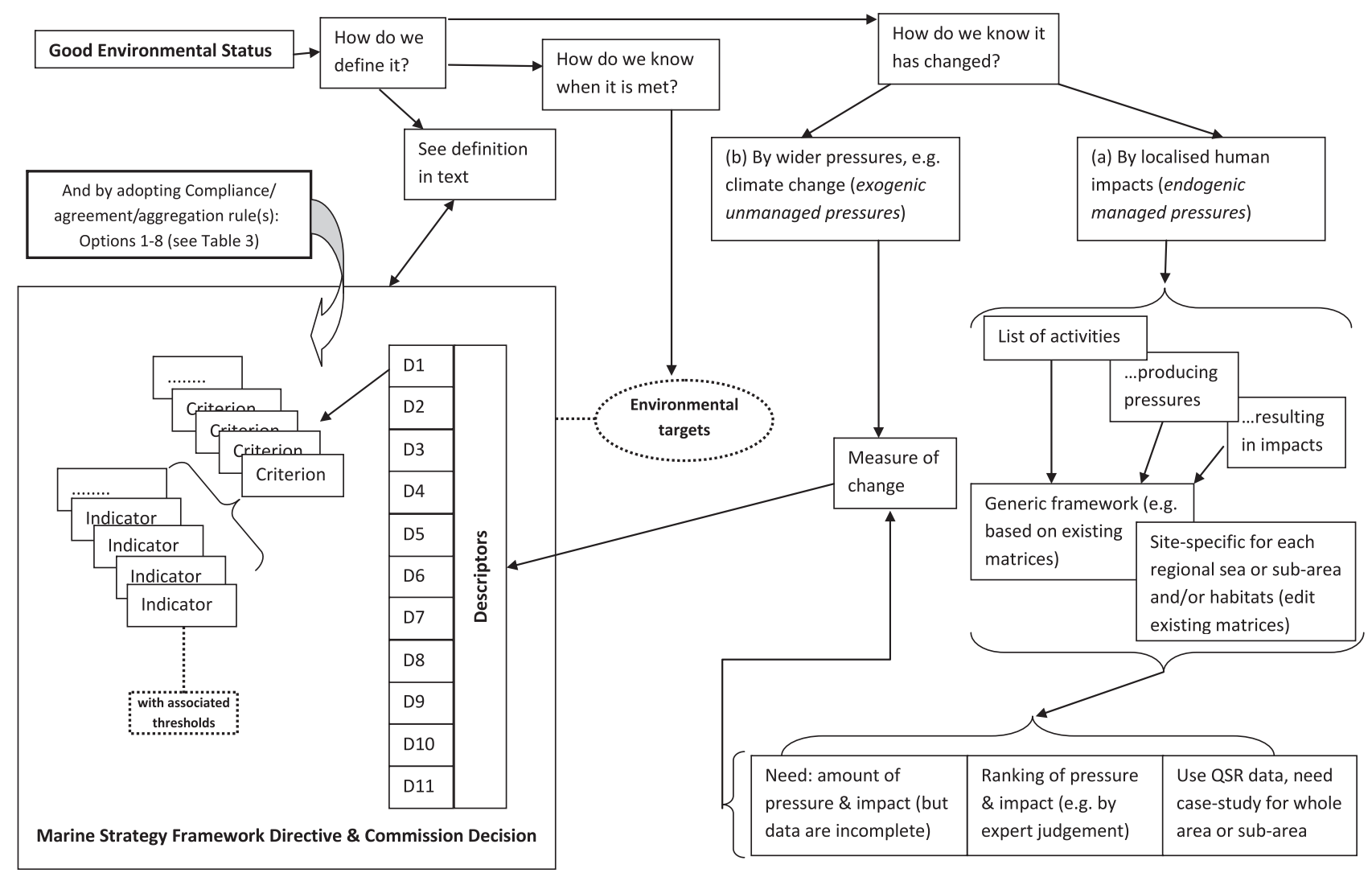

Fig. 2. Making operational the definition of Good Environmental Status. QSR: Quality Standard Reports. 


\section{Table}

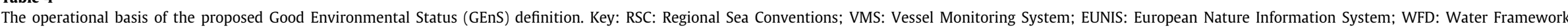

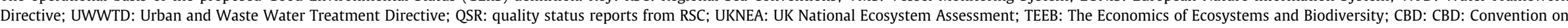
Biological Diversity.

\begin{tabular}{|c|c|c|c|c|}
\hline 'GEnS is achieved when..... & $\begin{array}{l}\text { Related to } \\
\text { which } \\
\text { descriptor? }\end{array}$ & How is this determined? & What data/information are available? & $\begin{array}{l}\text { Which targets or limits to be } \\
\text { used? }\end{array}$ \\
\hline $\begin{array}{l}\text {.....Physicochemical (including contaminants, litter and } \\
\text { noise)..... }\end{array}$ & $\begin{array}{l}5,6.8,9 \\
10,11\end{array}$ & $\begin{array}{l}\text { Rapid assessment of pressures using GIS and presented } \\
\text { via interactive .pdf documents; traditional sampling, } \\
\text { buoys (different sensors, including acoustic) }\end{array}$ & $\begin{array}{l}\text { Use of RSC databases to indicate the quality status of the } \\
\text { area (using QSR), summed point-source inputs of } \\
\text { contaminants; use of VMS for open sea fishing pressure; } \\
\text { RSC eutrophication maps }\end{array}$ & $\begin{array}{l}\text { Targets established in ad hoc } \\
\text { Directives (e.g. UWWTD, WFD, } \\
\text { Environmental Quality } \\
\text { Standards Directive, etc.) or } \\
\text { RSC }\end{array}$ \\
\hline $\begin{array}{l}\text {.....And hydrographical conditions are maintained at a } \\
\text { level..... }\end{array}$ & $1,6,7$ & $\begin{array}{l}\text { Remote measurements and aerial/satellite sensing; } \\
\text { habitat surveys; traditional sampling }\end{array}$ & $\begin{array}{l}\text { Seabed maps of selected areas, modelling of current } \\
\text { patterns, satellite data for surface conditions (waves, } \\
\text { currents, temperature, etc.). }\end{array}$ & RSC, expert judgment \\
\hline $\begin{array}{l}\text {.....Where the structuring components of the ecosystem } \\
\text { are present and functioning..... }\end{array}$ & $1,3,4,6$ & $\begin{array}{l}\text { Habitat maps, habitat suitability modelling, genomics, } \\
\text { traditional sampling, abundance estimates of key species } \\
\text { disparate survey data combined to give larger } \\
\text { assessments; assessments and indices of biological } \\
\text { functioning (productivity, competition, bioengineers, etc.) }\end{array}$ & $\begin{array}{l}\text { Broad biotope data (EUNIS), regional characterisation from } \\
\text { summed local surveys; mammal and bird recording } \\
\text { systems; fish stock assessments; specific surveys of } \\
\text { ecosystem functioning supported by literature from } \\
\text { elsewhere }\end{array}$ & $\begin{array}{l}\text { Habitats and Birds Directives } \\
\text { targets; Common Fisheries } \\
\text { Policy Targets; expert } \\
\text { judgement }\end{array}$ \\
\hline $\begin{array}{l}\text {.....Enabling the system to be resistant (ability to } \\
\text { withstand stress) and resilient (ability to recover } \\
\text { after a stressor) to harmful effects of human } \\
\text { pressures/activities/impacts..... }\end{array}$ & $\begin{array}{l}1,3,4,5,6 \\
8\end{array}$ & $\begin{array}{l}\text { Multimetric indices, functional indices, size-spectra } \\
\text { analyses; evidence of areas or components which have } \\
\text { recovered after stressors have been removed }\end{array}$ & $\begin{array}{l}\text { National and RSC databases Evidence from case-studies } \\
\text { and Environmental Impact Assessments and extrapolated } \\
\text { to wider areas; Alien and invasive species databases }\end{array}$ & $\begin{array}{l}\text { Adapted targets from other } \\
\text { directives (e.g. WFD) or RSC; } \\
\text { expert judgement }\end{array}$ \\
\hline $\begin{array}{l}\text {.....Where they maintain and provide the ecosystem } \\
\text { services..... }\end{array}$ & $\begin{array}{l}1,3,4,5,6 \\
7\end{array}$ & $\begin{array}{l}\text { An analysis of ecosystem services across sea areas, } \\
\text { Contingency valuation, biological valuation and other } \\
\text { economic valuation techniques }\end{array}$ & $\begin{array}{l}\text { A modelling and linked GIS analysis of habitats and } \\
\text { ecosystems to ecosystem services will be needed; data and } \\
\text { information from QSR }\end{array}$ & $\begin{array}{l}\text { None available; some } \\
\text { indicators of trends (e.g. } \\
\text { UKNEA, TEEB, CBD reports) } \\
\text { but not of targets (see Liquete } \\
\text { et al., 2013) }\end{array}$ \\
\hline ......That deliver societal benefits..... & $3,4,5,9$ & Economic valuation techniques & $\begin{array}{l}\text { Fisheries statistics, monitoring of seafood quality, } \\
\text { Databases of human uses; fisheries (VMS data), oil \& gas, } \\
\text { aggregate returns, etc. }\end{array}$ & $\begin{array}{l}\text { Legal limits for contaminants } \\
\text { in seafood, fish stocks under } \\
\text { safe limits, seabed extraction } \\
\text { within permits, etc. }\end{array}$ \\
\hline $\begin{array}{l}\text {....In a sustainable way (i.e. that pressures associated } \\
\text { with uses cumulatively do not hinder the ecosystem } \\
\text { components) in order to retain their natural } \\
\text { diversity, productivity and dynamic ecological } \\
\text { processes..... }\end{array}$ & $\begin{array}{l}1,2,3,4,5 \\
6\end{array}$ & $\begin{array}{l}\text { Productivity values and separation of natural from } \\
\text { anthropogenic production; alien and introduced species } \\
\text { are minimised }\end{array}$ & $\begin{array}{l}\text { National and RSC databases; use of data from small areas } \\
\text { extrapolated to larger areas; Alien and Invasive species } \\
\text { databases }\end{array}$ & $\begin{array}{l}\text { Legal limits for contaminants } \\
\text { in seafood, fish stocks under } \\
\text { safe limits; expert judgement }\end{array}$ \\
\hline $\begin{array}{l}\text {.....And where recovery is rapid and sustained if a use } \\
\text { ceases'..... }\end{array}$ & $\begin{array}{l}1,2,3,4,5 \\
6,8,9,10 \\
11\end{array}$ & $\begin{array}{l}\text { Traditional sampling, trend analysis, Evidence of areas or } \\
\text { components which have recovered after stressors have } \\
\text { been removed }\end{array}$ & $\begin{array}{l}\text { Long-term monitoring series; Alien and Invasive species } \\
\text { databases }\end{array}$ & $\begin{array}{l}\text { Trends showing a tendency } \\
\text { towards the previous state } \\
\text { (before pressure) (i.e. } \\
\text { hindcasting) }\end{array}$ \\
\hline
\end{tabular}


point-source problems (which may cover only a very small area) to indicate the quality status of the whole area. Furthermore, in keeping with the overall direction of the MSFD, and indeed the recently proposed Maritime Spatial Planning and Integrated Coastal Management Directive (European Commission, 2013), we emphasise in the definition and Table 4 the need for the marine environment to not only protect and enhance the nature conservation features but also to deliver ecosystem services and societal benefits.

While it is important to define what we mean by GEnS, Table 4 still emphasises the challenge of having sufficient methods and measurements to indicate when it has been achieved. While for certain elements we have a plethora of such agreed targets and limits, for example the levels of contaminants that should not be exceeded in water and seafood, for many others such limits are not yet defined. For example, while indicators have been proposed for many ecosystem services and societal benefits (e.g. see the review by Liquete et al. (2013)), these are to indicate the direction of trajectories (i.e. is a feature getting better or worse) rather than a level against which successful management is judged.

Consequently, there are a number of research and management needs. As shown here, there is a continuing and pressing need for scientists and policy makers to clarify the terminology across the different policy drivers, e.g. GEnS in MSFD, Favourable Conservation Status in the Habitats Directive, Good Ecological Status in the WFD, Ecological Quality Objectives of OSPAR, or approaches within the Convention on Biological Diversity. HELCOM (and OSPAR) has discussed this in detail (see HELCOM (2013) TARGREV report).

The relationship between the implementation of the MSFD and integrated maritime spatial planning is as yet poorly defined especially as much marine management is sector-based. Hence there is the need to integrate the monitoring and assessment across the policy drivers/descriptors, etc. It is necessary to assess the costs and benefits of co-location of marine activities and their effect on attaining GEnS and on the maintenance of ecosystem services and the delivery of societal benefits (Christie et al., in press). Thus, further research is required to produce a better understanding and more comprehensive datasets but also to concentrate on processes and cause and effect and to improve the science of monitoring especially to ask appropriate questions, determine key processes and give an interaction of components and processes.

Whichever way is used to define GEnS it will require an assessment of change against an expected standard or reference condition. While this has not yet been determined, once GEnS is determined then such a reference-deviation will be required as a management mechanism. However, given the difficulties of gathering data and the cost of producing data-rich means for defining reference conditions (i.e. comparisons with natural areas, hindcasting and predictive models), in the first instance reliance on expert judgement will be needed (Borja et al., 2012). An expert system that can capture expert judgement in a robust and defensible manner, as demonstrated across different continents (Teixeira et al., 2010), may be required.

As shown here and elsewhere, there is a plethora of indicators and targets and it is likely to be exceedingly difficult to reconcile the use of all of these, especially across the 11 descriptors-and it may well be unnecessary. They respond differently both in time and space, and might be counter-acting; although they may indicate poor quality in a small area, they will be absorbed across larger spatial scales and thus have little influence in an overall good quality eco-region. Consequently, we take the view that a combination of quantitative indicator targets and, where these are lacking, expert judgement are needed to integrate the natural and social science requirements for the sound implementation of the Marine Strategy Framework Directive.

\section{Acknowledgements}

This manuscript has resulted from the DEVOTES (DEVelopment Of innovative Tools for understanding marine biodiversity and assessing Good Environmental Status) project funded by the European Union under the 7th Framework Programme, 'The Ocean of Tomorrow' Theme (Grant Agreement No. 308392), www.devotesproject.eu. This paper is contribution number 654 from AZTITecnalia (Marine Research Division).

\section{References}

Atkins, J.P., Gregory, A.J., Burdon, D., Elliott, M., 2011a. Managing the marine environment: is the DPSIR framework holistic enough? Syst. Res. Behav. Sci. 28, 497-508.

Atkins, J.P., Burdon, D., Elliott, M., Gregory, A.J., 2011b. Management of the marine environment: integrating ecosystem services and societal benefits with the DPSIR framework in a systems approach. Mar. Pollut. Bull. 62 (2), 215-226.

Aubry, A., Elliott, M., 2006. The use of Environmental Integrative Indicators to assess seabed disturbance in estuaries and coasts: application to the Humber Estuary, UK. Mar. Pollut. Bull. 53 (1-4), 175-185.

Ban, N., Alder, J., 2008. How wild is the ocean? Assessing the intensity of anthropogenic marine activities in British Columbia, Canada. Aquat. Conserv.Mar. Freshwater Ecosyst. 18, 55-85.

Borja, Á., Elliott, M., 2013. Marine monitoring during an economic crisis: the cure is worse than the disease. Mar. Pollut. Bull. 68, 1-3.

Borja, Á., Rodríguez, J.G., 2010. Problems associated with the 'one-out, all-out' principle, when using multiple ecosystem components in assessing the ecological status of marine waters. Mar. Pollut. Bull. 60, 1143-1146.

Borja, A., Ranasinghe, A., Weisberg, S.B., 2009. Assessing ecological integrity in marine waters, using multiple indices and ecosystem components: challenges for the future. Mar. Pollut. Bull. 59, 1-4.

Borja, Á., Elliott, M., Carstensen, J., Heiskanen, A.-S., van de Bund, W., 2010. Marine management - towards an integrated implementation of the European Marine Strategy Framework and the Water Framework Directives. Mar. Pollut. Bull. 60, 2175-2186.

Borja, Á., Galparsoro, I., Irigoien, X., Iriondo, A., Menchaca, I., Muxika, I., Pascual, M., Quincoces, I., Revilla, M., Germán Rodríguez, J., Santurtún, M., Solaun, O. Uriarte, A., Valencia, V., Zorita, I., 2011. Implementation of the European Marine Strategy Framework Directive: a methodological approach for the assessment of environmental status, from the Basque Country (Bay of Biscay). Mar. Pollut. Bull. 62, 889-904.

Borja, Á., Dauer, D.M., Grémare, A., 2012. The importance of setting targets and reference conditions in assessing marine ecosystem quality. Ecol. Indic. 12, 1-7.

Bricker, S.B., Ferreira, J.G., Simas, T., 2003. An integrated methodology for assessment of estuarine trophic status. Ecol. Model. 169 (1), 39-60.

Cardoso, A.C., Cochrane, S., Doerner, H., Ferreira, J.G., Galgani, F., Hagebro, C., Hanke, G., Hoepffner, N., Keizer, P.D., Law, R., Olenin, S., Piet, G.J., Rice, J., Rogers, S.I., Swartenbroux, F., Tasker, M.L., van de Bund, W., 2010. Scientific Support to the European Commission on the Marine Strategy Framework Directive. Management Group Report. Office for Official Publications of the European Communities, EUR 24336 EN - Joint Research Centre, Luxembourg, p. 57.

Caroni, R., Bund, W., Clarke, R.T., Johnson, R.K., 2013. Combination of multiple biological quality elements into waterbody assessment of surface waters. Hydrobiologia 704, 437-451.

Carstensen, J., Conley, D.J., Andersen, J.H., Ærtebjerg, G., 2006. Coastal eutrophication and trend reversal: a Danish case study. Limnol. Oceanol. 51, 398-408.

Carstensen, J., Sánchez-Camacho, M., Duarte, C.M., Krause-Jensen, D., Marbà, N., 2011. Connecting the dots: responses of coastal ecosystems to changing nutrient concentrations. Environ. Sci. Technol. 45, 9122-9132.

Christie, N., Smyth, K., Barnes, R., Elliott, M., 2013. Co-location of activities and designations: a means of solving or creating problems in marine spatial planning? Marine Policy (in press). (http://dx.doi.org/10.1016/ j.marpol.2013.06.002).

Claussen, U., Connor, D., de Vrees, L., Leppänen, J., Percelay, J., Kapari, M., Mihail, O. Ejdung, G., Rendell, J., 2011. Common Understanding of (Initial) Assessment, Determination of Good Environmental Status (GES) and Establishment of Environmental Targets (Art. 8, 9 \& 10 MSFD). WG GES EU MSFD (<https:// circabc.europa.eu/sd/d/ce7e2776-6ac6-4a41-846f-a04832c32da7/05_Info_ Common_understanding_final.pdf $>$ ).

Cochrane, S.K.J., Connor, D.W., Nilsson, P., Mitchell, I., Reker, J., Franco, J., Valavanis, V., Moncheva, S., Ekebom, J., Nygaard, K., Serrao Santos, R., Naberhaus, I., Packeiser, T., van de Bund, W., Cardoso, A.C., 2010. Marine Strategy Framework Directive - Task Group 1 Report Biological Diversity. Office for Official Publications of the European Communities, EUR 24337 EN - Joint Research Centre, Luxembourg, p. 110.

Commission, O.S.P.A.R., 2010. Quality Status Report 2010. OSPAR Commission, London, p. 176.

De Jonge, V.N., Elliott, M., Brauer, V.S., 2006. Marine monitoring: its shortcomings and mismatch with the EU Water Framework Directive's objectives. Mar. Pollut. Bull. 53, 5-19. 
Duarte, C.M., Conley, D.J., Carstensen, J., Sánchez-Camacho, M., 2009. Return to Neverland: shifting baselines affect restoration targets. Estuaries Coasts 32, 2936.

Ehler, C., Douvere, F., 2009. Marine Spatial Planning: a step-by-step approach toward ecosystem-based management. Intergovernmental Oceanographic Commission and Man and the Biosphere Programme. UNESCO, Paris, IOC Manual and Guides No. 53, ICAM Dossier No. 6, p. 99.

Elliott, M., 2011. Marine science and management means tackling exogenic unmanaged pressures and endogenic managed pressures - a numbered guide. Mar. Pollut. Bull. 62, 651-655.

Elliott, M., Burdon, D., Hemingway, K.L., Apitz, S.E., 2007. Estuarine, coastal and marine ecosystem restoration: Confusing management and science - a revision of concepts. Estuar. Coast. Shelf Sci. 74, 349-366.

European Commission, 2000. Directive 2000/60/EC of the European Parliament and of the Council of 23 Octobre 2000 establishing a framework for community action in the field of water policy. Off. J. Eur. Union L327, 1-72.

European Commission, 2008. Directive 2008/56/EC of the European Parliament and of the Council establishing a framework for community action in the field of marine environmental policy (Marine Strategy Framework Directive). Off. J. Eur. Union L164, 19-40.

European Commission, 2010. Commission Decision of 1 September 2010 on criteria and methodological standards on good environmental status of marine waters (notified under document C(2010) 5956)(2010/477/EU). Off. J. Eur. Union L232 $12-24$.

European Commission, 2013. Proposal for a Directive of the European Parliament and of the Council establishing a framework for maritime spatial planning and integrated coastal management, p. 34.

Ferreira, J.G., Andersen, J.H., Borja, A., Bricker, S.B., Camp, J., Cardoso da Silva, M., Garcés, E., Heiskanen, A.S., Humborg, C., Ignatiades, L., Lancelot, C., Menesguen, A., Tett, P., Hoepffner, N., Claussen, U., 2010. Marine Strategy Framework Directive - Task Group 5 Report Eutrophication. Office for Official Publications of the European Communities, EUR 24338 EN - Joint Research Centre, Luxembourg, p. 49.

Ferreira, J.G., Andersen, J.H., Borja, A., Bricker, S.B., Camp, J., Cardoso da Silva, M., Garcés, E., Heiskanen, A.-S., Humborg, C., Ignatiades, L., Lancelot, C., Menesguen, A., Tett, P., Hoepffner, N., Claussen, U., 2011. Overview of eutrophication indicators to assess environmental status within the European Marine Strategy Framework Directive. Estuar. Coast. Shelf Sci. 93, 117-131.

Foley, N.S., van Rensburg, T.M., Armstrong, C.W., 2010. The ecological and economic value of deep water corals. Ocean Coast. Manage. 53, 313-326.

Galgani, F., Fleet, D., van Franeker, J., Katsanevakis, S., Maes, T., Mouat, J., Oosterbaan, L., Poitou, I., Hanke, G., Thompson, R., Amato, E., Birkun, A. Janssen, C., 2010. Marine Strategy Framework Directive - Task Group 10 Report Marine litter. Office for Official Publications of the European Communities, EUR 24340 EN - Joint Research Centre, Luxembourg, p. 48.

Halpern, B.S., Walbridge, S., Selkoe, K.A., Kappel, C.V., Micheli, F., D’Agrosa, C., Bruno, J.F., Casey, K.S., Ebert, C., Fox, H.E., Fujita, R., Heinemann, D., Lenihan, H.S., Madin, E.M.P., Perry, M.T., Selig, E.R., Spalding, M., Steneck, R., Watson, R., 2008. A global map of human impact on marine ecosystems. Science 319, 948-952.

Halpern, B.S., Longo, C., Hardy, D., McLeod, K.L., Samhouri, J.F., Katona, S.K., Kleisner, K., Lester, S.E., O'Leary, J., Ranelletti, M., Rosenberg, A.A., Scarborough, C., Selig E.R., Best, B.D., Brumbaugh, D.R., Chapin, F.S., Crowder, L.B., Daly, K.L., Doney, S.C., Elfes, C., Fogarty, M.J., Gaines, S.D., Jacobsen, K.I., Karrer, L.B., Leslie, H.M., Neeley, E., Pauly, D., Polasky, S., Ris, B., St Martin, K., Stone, G.S., Sumaila, U.R., Zeller, D., 2012. An index to assess the health and benefits of the global ocean. Nature 488, 615-620.

Harding, L.E., 1992. Measures of marine environmental quality. Mar. Pollut. Bull. 25, 23-27.

Heiskanen, A.-S., van de Bund, W.J., Cardoso, A.C., Nõges, P., 2004. Towards good ecological status of surface waters in Europe - Interpretation and harmonisation of the concept. Water Sci. Technol. 49 (7), 169-177.

HELCOM, 2010. Ecosystem Health of the Baltic Sea 2003-2007: HELCOM Initial Holistic Assessment. Baltic Sea Environment Proceedings, No. 122, p. 63 (<http://www.helcom.fi>).

HELCOM, 2013. Approaches and methods for eutrophication target setting in the Baltic Sea region. Baltic Sea Environment Proceedings, No. 133. (<http:// www.helcom.fi>).

Hering, D., Borja, A., Carstensen, J., Carvalho, L., Elliott, M., Feld, C.K., Heiskanen, A. S., Johnson, R.K., Moe, J., Pont, D., Solheim, A.L., van de Bund, W., 2010. The European Water Framework Directive at the age of 10: a critical review of the achievements with recommendations for the future. Sci. Total Environ. 408, 4007-4019.

Korpinen, S., Meski, L., Andersen, J.H., Laamanen, M., 2012. Human pressures and their potential impact on the Baltic Sea ecosystem. Ecol. Indic. 15, 105-114.

Law, R., Hanke, G., Angelidis, M., Batty, J., Bignert, A., Dachs, J., Davies, I., Denga, Y., Duffek, A., Herut, B., Hylland, K., Lepom, P., Leonards, P., Mehtonen, J., Piha, H.,
Roose, Tronczynski, J., Velikova, V., Vethaak, D., 2010. Marine Strategy Framework Directive - Task Group 8 Report Contaminants and Pollution Effects. Office for Official Publications of the European Communities, EUR 24335 EN - Joint Research Centre, Luxembourg, p. 161.

Liquete, C.. Piroddi, C., Drakou, E.G., Gurney, L., Katsanevakis, S., Charef, A., Egoh, B. 2013. Current status and future prospects for the assessment of marine and coastal ecosystem services: a systematic review. PLoS One 8, e67737.

Mee, L.D., Jefferson, R.L., Laffoley, D.d.A., Elliott, M., 2008. How good is good? Human values and Europe's proposed Marine Strategy Directive. Mar. Pollut. Bull. 56, 187-204.

Mouillot, D., Bellwood, D.R., Baraloto, C., Chave, J., Galzin, R., Harmelin-Vivien, M., Kulbicki, M., Lavergne, S., Lavorel, S., Mouquet, N., Paine, C.E.T., Renaud, J. Thuiller, W., 2013. Rare species support vulnerable functions in high-diversity ecosystems. PLoS Biol. 11, e1001569.

Olenin, S., Alemany, F., Cardoso, A.C., Gollasch, S., Goulletquer, P., Lehtiniemi, M., McCollin, T., Minchin, D., Miossec, L., Occhipinti-Ambrogi, A., Ojaveer, H., Rose Jensen, K., Stankiewicz, M., Wallentinus, I., Aleksandrov, B., 2010. Marine Strategy Framework Directive - Task Group 2 Report Non-indigenous Species. Office for Official Publications of the European Communities, EUR 24342 EN Joint Research Centre, Luxembourg, p. 44.

Pascual, M., Borja, A., Franco, J., Burdon, D., Atkins, J.P., Elliott, M., 2012. What are the costs and benefits of biodiversity recovery in a highly polluted estuary? Water Res. 46, 205-217.

Piet, G.J., Albella, A.J., Aro, E., Farrugio, H., Lleonart, J., Lordan, C., Mesnil, B., Petrakis, G., Pusch, C., Radu, G., Ratz, H.J., 2010. Marine Strategy Framework Directive Task Group 3 Report Commercially Exploited Fish and Shellfish. Office for Official Publications of the European Communities, EUR 24316 EN - Joint Research Centre, Luxembourg, p. 82.

Rice, J., Arvanitidis, C., Borja, A., Frid, C., Hiddink, J., Krause, J., Lorance, P., Ragnarsson, S.A., Skold, M., Trabucco, B., 2010. Marine Strategy Framework Directive - Task Group 6 Report Seafloor Integrity. Office for Official Publications of the European Communities, EUR 24334 EN - Joint Research Centre, Luxembourg, p. 73.

Rogers, S., Casini, M., Cury, P., Heath, M., Irigoien, X., Kuosa, H., Scheidat, M., Skov, H., Stergiou, K.I., Trenkel, V.M., Wikner, J., Yunev, O., 2010. Marine Strategy Framework Directive - Task Group 4 Report Food Webs. Office for Official Publications of the European Communities, EUR 24343 EN - Joint Research Centre, Luxembourg, p. 55.

Solheim, A.L., Austnes, K., Kristensen, P., Peterlin, M., Kodes, V., Collins, R., Semeradova, S., Künitzer, A., Filippi, R., Prchalová, H., Spiteri, C., Prins, T., 2012. Ecological and chemical status and pressures in European waters. Thematic assessment for EEA Water 2012 Report. ETC./ICM Technical Report, vol. 1, p. 146.

Swartenbroux, F., Albajedo, B., Angelidis, M., Aulne, M., Bartkevics, V., Besada, V., Bignert, A., Bitterhof, A., Hallikainen, A., Hoogenboom, R., Jorhem, L., Jud, M., Law, R., Licht Cederberg, D., McGovern, E., Miniero, R., Schneider, R., Velikova, V., Verstraete, F., Vinas, L., Vlad, S., 2010. Marine Strategy Framework Directive Task Group 9 Report Contaminants in Fish and Other Seafood. Office for Official Publications of the European Communities, EUR 24339 EN - Joint Research Centre, Luxembourg, p. 36.

Tasker, M.L., Amundin, M., Andre, M., Hawkins, A., Lang, W., Merck, T., ScholikSchlomer, A., Teilmann, J., Thomsen, F., Werner, S., Zakharia, M., 2010. Marine Strategy Framework Directive - Task Group 11 Report. Underwater Noise and Other Forms of Energy. Office for Official Publications of the European Communities, EUR 24341 EN - Joint Research Centre, Luxembourg, p. 55.

Teixeira, H., Borja, Á., Weisberg, S.B., Ananda Ranasinghe, J., Cadien, D.B., Dauer, D.M., Dauvin, J.-C., Degraer, S., Diaz, R.J., Grémare, A., Karakassis, I., Llansó, R.J., Lovell, L.L., Marques, J.C., Montagne, D.E., Occhipinti-Ambrogi, A., Rosenberg, R. Sardá, R., Schaffner, L.C., Velarde, R.G., 2010. Assessing coastal benthic macrofauna community condition using best professional judgement developing consensus across North America and Europe. Mar. Pollut. Bull. 60, 589-600.

Ten Brink, B.J.E., Hosper, S.H., Colijn, F., 1991. A quantitative method for description and assessment of ecosystems: the AMOEBA - approach. Mar. Pollut. Bull. 23, 265-270.

Tett, P., Gowen, R., Painting, S., Elliott, M., Forster, R., Mills, D., Bresnan, E., Capuzzo, E., Fernandes, T., Foden, J., Geider, R., Gilpin, L., Huxham, M., McQuatters-Gollop, A., Malcolm, S., Saux-Picart, S., Platt, T., Racault, M.F., Sathyendranath, S., van der Molen, J., Wilkinson, M., 2013. A Framework for understanding marine ecosystem health. Mar. Ecol. Prog. Ser. (in press). http://dx.doi.org/10.3354/ meps10539

UNCLOS, 1982. United Nations Convention on the Law of the Sea, signed at Montego Bay, Jamaica, on 10 December 1982, p. 202, <http://www.un.org/Depts/los/ index.htm>. 